\title{
Genetic parameters for major milk proteins in Dutch Holstein-Friesians
}

\author{
G. C. B. Schopen, ${ }^{\star 1}$ J. M. L. Heck, † H. Bovenhuis, ${ }^{\star}$ M. H. P. W. Visker, ${ }^{\star}$ H. J. F. van Valenberg,† \\ and J. A. M. van Arendonk* \\ *Animal Breeding and Genomics Centre, Wageningen University, PO Box 338, $6700 \mathrm{AH}$ Wageningen, the Netherlands \\ †Dairy Science and Technology, Wageningen University, PO Box 8129, 6700 EV Wageningen, the Netherlands
}

\section{ABSTRACT}

The objective of this study was to estimate genetic parameters for major milk proteins. One morning milk sample was collected from 1,940 first-parity HolsteinFriesian cows in February or March 2005. Each sample was analyzed with capillary zone electrophoresis to determine the relative concentrations of the 6 major milk proteins. The results show that there is considerable genetic variation in milk protein composition. The intraherd heritabilities for the relative protein concentrations were high and ranged from 0.25 for $\beta$-casein to 0.80 for $\beta$-lactoglobulin. The intraherd heritability for the summed whey fractions (0.71) was higher than that for the summed casein fractions (0.41). Further, there was relatively more variation in the summed whey fraction (coefficient of variation was $11 \%$ and standard deviation was 1.23) compared with the summed casein fraction (coefficient of variation was $2 \%$ and standard deviation was 1.72). For the caseins and $\alpha$-lactalbumin, the proportion of phenotypic variation explained by herd was approximately $14 \%$. For $\beta$-lactoglobulin, the proportion of phenotypic variation explained by herd was considerably lower (5\%). Eighty percent of the genetic correlations among the relative contributions of the major milk proteins were between -0.38 and +0.45 . The genetic correlations suggest that it is possible to change the relative proportion of caseins in milk. Strong negative genetic correlations were found for $\beta$-lactoglobulin with the summed casein fractions $(-0.76)$, and for $\beta$-lactoglobulin with casein index $(-0.98)$. This study suggests that there are opportunities to change the milk protein composition in the cow's milk using selective breeding.

Key words: protein composition, heritability, genetic correlation, Dutch Holstein-Friesian

Received April 18, 2008.

Accepted October 29, 2008

${ }^{1}$ Corresponding author: ghyslaine.schopen@wur.nl

\section{INTRODUCTION}

Bovine milk represents a unique source of bioactive components and nutrients, which include proteins. The major milk proteins are $\alpha_{\mathrm{S}^{-}} \mathrm{CN}, \alpha_{\mathrm{S}^{2}} \mathrm{CN}, \beta-\mathrm{CN}, \kappa-\mathrm{CN}$, $\alpha$-LA, and $\beta$-LG. The protein composition of milk plays an important role in the profitability of the dairy industry. Specific proteins contribute to the production of specific milk products. Caseins, for example, are important for cheese yield, milk coagulation time, and curd firmness (Wedholm et al., 2006), whereas $\beta$-LG is important for the heat stability of milk (Feagan, 1979). To explore the possibilities of altering milk protein composition by selective breeding, genetic parameters such as heritability and genetic covariance are needed. Although many studies have reported the genetic variation for protein percentages and protein yields (Hayes et al., 1984; Bobe et al., 1999; Ikonen et al., 2004), only a few studies have estimated the magnitude of the genetic variation of milk proteins (Renner and Kosmack, 1975; Kroeker et al., 1985; Ikonen et al., 1997; Bobe et al., 1999; Graml and Pirchner, 2003). Furthermore, these studies estimated the heritability of the major milk proteins, but no studies have reported genetic correlations among the major milk proteins. The limited number of studies is a reflection of the technological difficulties of quantifying the 6 major bovine milk proteins simultaneously on a large number of cows and daughters of bulls, which is a prerequisite for estimating their genetic parameters.

In the present study, capillary zone electrophoresis (CZE) was used to separate the major milk proteins. This technique provides rapid separation of the proteins, high resolution, and is reproducible (Heck et al., 2008). Heck et al. (2008) showed that the protein composition of milk varies substantially among cows at the phenotypic level. However, it is not known to what extent this variation arises from genetic factors.

The objective of this study was to estimate the heritability of milk protein composition and to estimate the genetic and phenotypic correlations among the major milk proteins and of milk protein composition with milk production traits in a population of 1,940 Dutch Holstein-Friesian cows. 
MATERIALS AND METHODS

\section{Animals}

As part of the Dutch Milk Genomics Initiative, information was collected on 1,940 first-parity cows, distributed over 398 commercial herds throughout the Netherlands. At least 3 cows were selected per herd, and each cow was at least $87.5 \%$ Holstein-Friesian. The cows descended from 1 of 5 proven bulls (899 cows), from 1 of 50 test bulls (849 cows), or from 1 of 15 other proven bulls (192 cows). The last group of cows ensured sampling of at least 3 cows per herd. The pedigree of the cows was supplied by the CRV (Arnhem, the Netherlands). The cows were milked twice daily; and each cow was between d 63 and 282 of lactation at the time of sampling. Almost all animals have also been used in previous studies for the genetic analysis of urea (Stoop et al., 2007) and milk fatty acid composition (Schennink et al., 2007; Stoop et al., 2008). A morning milk sample was collected from each cow during February and March 2005, which is the winter period, to be used in the analysis of the major milk proteins.

\section{Phenotypes}

Observations of the test-day morning milk yield were obtained from the CRV. True protein, fat, and lactose percentages were determined by infrared spectroscopy using a Fourier-transformed interferogram (MilkoScan FT 6000, Foss Electric, Hillerød, Denmark) at the milk control station laboratory (Zutphen, the Netherlands). Protein, fat, and lactose yields were calculated by multiplying the respective percentages by the observed milk yield. Morning milk yields were missing for 147 cows; therefore, only 1,793 records were analyzed for protein, fat, and lactose yields.

The relative concentrations of the 6 major milk proteins were determined by CZE, which is a technique used to separate proteins based on differences in size and charge. Using this method, we quantified $\alpha_{S_{1}} \mathrm{CN}$, $\alpha_{\mathrm{S}_{2}} \mathrm{CN}, \beta-\mathrm{CN}, \kappa-\mathrm{CN}, \alpha-\mathrm{LA}$, and $\beta$-LG. They were expressed as a percentage of the total protein fraction. Heck et al. (2008) provides a detailed description of the CZE technique used in this study.

The milk protein $\kappa-\mathrm{CN}$, as determined in our study, consisted only of $\kappa$-CN-1P (nonglycosylated, monophosphorylated state; Heck et al., 2008). Sum casein ( $\boldsymbol{\Sigma}$ casein) was defined as the sum of the percentages of $\alpha_{S_{1}}-\mathrm{CN}, \alpha_{\mathrm{S}_{2}} \mathrm{CN}, \beta-\mathrm{CN}$, and $\kappa-\mathrm{CN}$. Sum whey ( $\boldsymbol{\Sigma}$ whey) was calculated by adding the percentages of $\alpha$-LA and $\beta$-LG. Furthermore, casein yield was calculated by multiplying $\Sigma$ casein by total protein yield. The casein index was calculated as

$$
\text { casein index }=\frac{\Sigma \text { casein }}{\Sigma \text { casein }+\Sigma \text { whey }} \times 100 \text {. }
$$

\section{Genotypes}

Blood samples of cows for DNA isolation were collected. Genotypes for the $\kappa-\mathrm{CN}$ C5309T, $\kappa-\mathrm{CN}$ A5345C, and $\kappa-\mathrm{CN}$ A5365G (the latter 3 to enable genotyping of $\kappa-\mathrm{CN}$ variants $\mathrm{A}, \mathrm{B}$, and $\mathrm{E}$ ) polymorphisms had been genotyped using a SNaPshot assay (Applied Biosystems, Foster City, CA; Schennink et al., 2008; Heck et al., 2009). Genotypes for $\kappa$-CN were missing for 208 cows because no DNA sample was available or the DNA sample could not be genotyped unambiguously. The $\beta-\mathrm{CN}$ and $\beta-\mathrm{LG}$ genotypes were determined by CZE and confirmed by genotyping $2 \beta-\mathrm{CN}$ polymorphisms and $1 \beta$-LG polymorphism for 849 genotyped cows by the Illumina Golden Gate assay (Illumina, San Diego, CA; Heck et al., 2009).

\section{Statistical Analysis}

To estimate the genetic parameters and variance components, ASReml was used (Gilmour et al., 2002). The following animal model was used in the analyses:

$$
\begin{aligned}
& \mathrm{y}_{\mathrm{ijklmn}}=\mu+\mathrm{b}_{1} \times \text { lactst }_{\mathrm{i}}+\mathrm{b}_{2} \times \mathrm{e}^{-0.05 \times \text { lactst }_{\mathrm{i}}} \\
&+\mathrm{b}_{3} \times \mathrm{ca}_{\mathrm{j}}+\mathrm{b}_{4} \times \mathrm{ca}_{\mathrm{j}}{ }^{2}+\text { season }_{\mathrm{k}}+\text { scode }_{\mathrm{l}} \\
&+\operatorname{animal}_{\mathrm{m}}+\operatorname{herd}_{\mathrm{n}}+\mathrm{e}_{\mathrm{ijklmn}},
\end{aligned}
$$

where $\mathrm{y}_{\mathrm{ijk} k \mathrm{mn}}$ was the observation for animal $m$ in herd $n$ with sire-code $l$, season $k$, calving age $j$, and lactation day $i$ for the trait of interest. The overall mean of the trait was $\mu$, lactst $_{i}$ was a covariate describing the effect of day $i$ of lactation, $\mathrm{ca}_{\mathrm{j}}$ was a covariate describing the effect of age at first calving in $j$ days, season $_{k}$ was the fixed effect of the $k$ th class of calving season [3 classes: summer (June-August 2004), autumn (SeptemberNovember 2004), and winter (December 2004-February 2005)], scode was $_{1}$ the fixed effect of the $l$ th class of the 3 different sire groups, animal $\mathrm{m}_{\mathrm{m}}$ was the random additive genetic effect of animal $m$, herd $\mathrm{n}_{\mathrm{n}}$ was a random herd effect of the $n$th herd, and $\mathrm{e}_{\mathrm{ijk} k \mathrm{mn}}$ was the random residual effect. Effects of the $\beta-\mathrm{CN}, \kappa-\mathrm{CN}$, and $\beta-\mathrm{LG}$ polymorphisms were estimated using the same animal model as described above and including a milk protein genotype as a fixed effect in the animal model. Ungenotyped animals were included as a separate class.

The variance-covariance structure of the additive genetic effects was $\operatorname{Var}($ animal $)=A \sigma_{a}^{2}$, where A was a matrix of additive genetic relationships among indi- 
viduals and $\sigma_{a}^{2}$ was the additive genetic variation. The variance-covariance structure of the herd effects was $\operatorname{Var}($ herd $)=I \sigma_{\text {herd }}^{2}$, where I was the identity matrix and $\sigma_{\text {herd }}^{2}$ was the herd variation. Univariate analyses were used to estimate the intraherd heritability, which was defined as

$$
h^{2}=\frac{\sigma_{a}^{2}}{\sigma_{a}^{2}+\sigma_{e}^{2}},
$$

where $\sigma_{a}^{2}$ was the additive genetic variation and $\sigma_{e}^{2}$ was the residual variation.

The proportion of the total phenotypic variation due to differences among herds was defined as

$$
h_{\text {herd }}=\frac{\sigma_{\text {herd }}^{2}}{\sigma_{\text {herd }}^{2}+\sigma_{a}^{2}+\sigma_{e}^{2}},
$$

where $\sigma_{\text {herd }}^{2}$ was the herd variation, $\sigma_{a}^{2}$ was the additive genetic variation, and $\sigma_{e}^{2}$ was the residual variation.

For estimating genetic and phenotypic correlations among the different milk proteins and of milk proteins with milk production traits, bivariate analyses were performed using model [1].

\section{RESULTS}

\section{Mean, Standard Deviation, and Coefficient of Variation}

The means, standard deviations, and coefficients of variation for the protein composition of milk and traits of milk production are in Table 1. The percentage of protein in the 1,940 morning milk samples averaged $3.5 \%$. The 6 major milk proteins evaluated in this study made up about $86 \%$ of the total protein fraction (Table 1 ). The remaining $14 \%$ consisted of glycosylated and multiphosphorylated $\kappa$-CN, BSA, $\gamma$-caseins, proteose peptones, immunoglobulins, lactoferrin, and numerous other proteins that occur in very low concentrations. Although BSA can be well separated using CZE, it is difficult to quantify with CZE because of sticking to the capillary. The other proteins are very heterogeneous and could not be quantified with an acceptable reproducibility. The glycosylated and multiphosphorylated form of $\kappa$-CN partly co-migrates with $\beta$-CN, which leads to a less accurate estimation of the total amount of $\beta-\mathrm{CN}$ (Heck et al., 2009).
Of total protein, $75 \%$ was made up of the caseins ( $\Sigma$ casein). The main caseins were $\alpha_{\mathrm{S}_{1}} \mathrm{CN}$ and $\beta-\mathrm{CN}$, which made up 34 and $27 \%$ of the total protein, respectively. Four percent of the total protein fraction was $\kappa-\mathrm{CN}$, which consisted of $\kappa-\mathrm{CN}$ only in the monophosphorylated form. The CV for $\alpha_{S 1}-\mathrm{CN}$ was $5 \%$ and for $\beta$-CN was $6 \%$. There was little variation in $\Sigma$ casein; the SD was 1.72 and the $\mathrm{CV}$ was $2 \%$. The SD for $\kappa-\mathrm{CN}$ was about one-third that of the other 3 caseins. The major whey protein was $\beta-\mathrm{LG}$, which made up $8 \%$ of the total protein fraction, and $\Sigma$ whey was $11 \%$ of the total protein. The CV for $\Sigma$ whey was $11 \%$, nearly 5 times higher than that of $\Sigma$ casein $(2 \%)$. The SD for $\alpha$-LA was about one-fourth that of $\beta$-LG. A low CV was found for the casein index $(2 \%)$. We found that $90 \%$ of the cows had a casein index between 85 and 90 . Milk yield averaged $13.5 \mathrm{~kg}$ based on a test-day morning milk sample (Table 1).

\section{Intraherd Heritability}

The intraherd heritability is given in Table 2. For the relative contribution of the proteins to the total milk protein, the intraherd heritability was moderate to high and ranged from 0.25 for $\beta$-CN to 0.80 for $\beta$-LG. Notably, the intraherd heritability for $\alpha_{\mathrm{S}^{-}} \mathrm{CN}(0.47)$ was almost twice that for $\beta$-CN, but the intraherd heritability for $\alpha_{\mathrm{S}_{2}} \mathrm{CN}(0.73)$ was similar to that for $\kappa-\mathrm{CN}$ (0.64). The intraherd heritability for $\beta-L G$ was higher than that for $\alpha$-LA (0.55).

The extent to which single milk protein polymorphisms ( $\beta-\mathrm{CN}, \kappa-\mathrm{CN}$, or $\beta-\mathrm{LG})$ could explain the additive genetic variation in milk protein fractions (Table 2 ) was explored. Accounting for $\beta-\mathrm{CN}$ genotypes reduced the polygenic, additive genetic variance for $\beta-\mathrm{CN}$ concentration from 0.54 to 0.47 . Accounting for $\kappa$ - $\mathrm{CN}$ genotypes reduced the polygenic additive genetic variance for $\kappa-\mathrm{CN}$ concentration from 0.19 to 0.12 , and accounting for $\beta$-LG genotypes reduced the polygenic additive genetic variance for $\beta$-LG from 1.14 to 0.11 . Further, milk protein genotypes had a substantial effect on the estimated polygenic genetic variance for $\Sigma$ casein and casein index.

For the traits of milk production, the intraherd heritability was 0.66 for protein percentage and 0.24 for protein yield. The intraherd heritability for lactose yield was similar to the intraherd heritability for milk yield.

\section{Proportion of Phenotypic Variation Explained by Herd}

The proportion of phenotypic variation explained by herd is also given in Table 2. For the caseins, the 
Table 1. Means, standard deviations, coefficients of variation, and 5\% and 95\% quantiles for milk protein composition and milk production traits, measured on test-day morning milk samples from 1,940 first-lactation cows

\begin{tabular}{|c|c|c|c|c|c|}
\hline Trait & Mean & $\mathrm{SD}$ & $\mathrm{CV}(\%)$ & $5 \%$ quantile & $95 \%$ quantile \\
\hline \multicolumn{6}{|c|}{ Milk protein composition ${ }^{1}$} \\
\hline$\alpha_{\mathrm{S} 1}-\mathrm{CN}$ & 33.62 & 1.70 & 5 & 30.90 & 36.13 \\
\hline$\alpha_{\mathrm{S}^{-}} \mathrm{CN}$ & 10.38 & 1.41 & 14 & 8.03 & 12.59 \\
\hline$\beta-\mathrm{CN}$ & 27.17 & 1.60 & 6 & 24.51 & 29.70 \\
\hline$\kappa-\mathrm{CN}^{2}$ & 4.03 & 0.58 & 14 & 3.10 & 4.98 \\
\hline$\alpha-\mathrm{LA}$ & 2.44 & 0.32 & 13 & 1.94 & 2.95 \\
\hline$\beta-\mathrm{LG}$ & 8.35 & 1.20 & 14 & 6.29 & 10.29 \\
\hline$\Sigma$ casein $^{3}$ & 75.20 & 1.72 & 2 & 72.46 & 77.76 \\
\hline Ewhey ${ }^{4}$ & 10.79 & 1.23 & 11 & 8.73 & 12.78 \\
\hline Casein index ${ }^{5}$ & 87.45 & 1.40 & 2 & 85.19 & 89.79 \\
\hline Casein yield ${ }^{6}(\mathrm{~kg})$ & 0.35 & 0.07 & 20 & 0.24 & 0.47 \\
\hline \multicolumn{6}{|l|}{ Milk production traits } \\
\hline Milk yield ${ }^{7}(\mathrm{~kg})$ & 13.46 & 2.73 & 20 & 9.00 & 18.10 \\
\hline Protein $(\%)$ & 3.51 & 0.30 & 9 & 3.04 & 4.01 \\
\hline Fat $(\%)$ & 4.36 & 0.71 & 16 & 3.33 & 5.48 \\
\hline Lactose (\%) & 4.64 & 0.14 & 3 & 4.41 & 4.85 \\
\hline Protein yield ${ }^{7}(\mathrm{~kg})$ & 0.47 & 0.09 & 19 & 0.32 & 0.61 \\
\hline Fat yield $(\mathrm{kg})$ & 0.58 & 0.11 & 19 & 0.40 & 0.76 \\
\hline Lactose yield ${ }^{7}(\mathrm{~kg})$ & 0.62 & 0.13 & 21 & 0.42 & 0.84 \\
\hline
\end{tabular}

${ }^{1}$ Expressed as percentage of the total protein fraction (wt/wt), except for casein yield.

${ }^{2}$ Only $\kappa$-CN in the nonglycosylated mono-phosphorylated form.

${ }^{3} \Sigma$ casein $=\alpha_{\mathrm{S}^{-}} \mathrm{CN}+\alpha_{\mathrm{S}^{2}} \mathrm{CN}+\beta-\mathrm{CN}+\kappa-\mathrm{CN}$.

${ }^{4} \Sigma$ whey $=\alpha-\mathrm{LA}+\beta-\mathrm{LG}$.

${ }^{5}$ Casein index $=\Sigma$ casein $/(\Sigma$ casein $+\Sigma$ whey $) \times 100$.

${ }^{6}$ Casein yield $=\Sigma$ casein $\times$ protein yield.

${ }^{7}$ Based on 1,793 morning milk samples.

proportion of phenotypic variation was approximately $14 \%$. For $\beta$-LG, the proportion of phenotypic variation explained by herd was $5 \%$, but the variation of $\alpha$-LA (16\%) was similar to that of the caseins. For the milk production traits, the proportion of phenotypic variation explained by herd ranged from $6 \%$ for lactose percentage to $36 \%$ for protein yield.

To compare the proportions of variation due to genetics and due to herd, the ratio of additive genetic variation and herd variation was calculated (Table 2). For protein yield and casein yield, herd variation was larger than additive genetic variation, but for the other milk proteins and milk production traits, additive genetic variation was similar or larger than herd variation.

\section{Genetic Correlations Among the Milk Proteins}

Phenotypic correlations were similar to the genetic correlations (Table 3), indicating that environmental correlations are similar to genetic correlations. We will focus on the genetic correlations. Among the relative contributions of the major milk proteins to total milk protein, $80 \%$ of the genetic correlations were between -0.38 and +0.45 . The genetic correlations among the 4 caseins were low to moderate. The strongest genetic correlations among the caseins were between $\alpha_{S_{1}}-\mathrm{CN}$ and $\alpha_{S_{2}}-\mathrm{CN}(-0.49)$, and between $\alpha_{S^{-}} \mathrm{CN}$ and $\kappa-\mathrm{CN}$
$(-0.56)$. The strongest genetic correlations among all milk proteins were found among $\Sigma$ casein, $\Sigma$ whey, and the casein index. A strong negative correlation was found for $\Sigma$ casein with $\beta$-LG $(-0.76)$ or $\Sigma$ whey $(-0.70)$, but $\Sigma$ casein was strongly positively correlated with the casein index (0.77). A strong positive correlation was observed between $\Sigma$ whey and $\beta$-LG (0.98), but $\Sigma$ whey was strongly negatively correlated with the casein index $(-1.00)$. The casein index was strongly negatively correlated with $\beta$-LG $(-0.98)$.

Adjusting the data for $\beta$-LG genotypes gave similar correlations to those reported in Table 3, in most cases. The most important changes were the genetic correlation between $\Sigma$ casein and $\Sigma$ whey, which increased from -0.70 to -0.28 , the genetic correlation between $\Sigma$ whey and $\alpha$-LA, which changed from -0.14 to 0.20 , the genetic correlation between $\Sigma$ whey and $\alpha_{S_{1}-} \mathrm{CN}$, which changed from -0.07 to 0.35 , and the genetic correlation between casein index and $\alpha_{S_{1}} \mathrm{CN}$, which changed from 0.10 to -0.25 .

\section{Genetic Correlations Among Individual Milk Proteins and Milk Production Traits}

Table 4 shows the genetic correlations between the different milk proteins and milk production traits. The protein percentage was negatively correlated with $\alpha_{\mathrm{S} 1^{-}}$ 


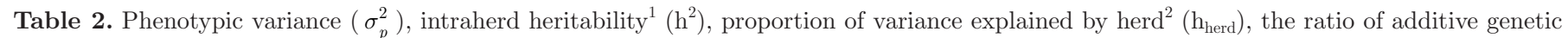
variation to herd variation $\left(\sigma_{a}^{2} / \sigma_{\text {herd }}^{2}\right)$, and additive genetic variance without accounting for milk protein genotypes ( $\left.\sigma_{a}^{2}\right)$, with accounting for single $\beta$-CN $\left(\sigma_{a B C N}^{2}\right), \kappa-C N\left(\sigma_{a K C N}^{2}\right)$, or $\beta$-LG $\left(\sigma_{a B L G}^{2}\right)$ genotypes for milk protein composition and milk production traits, measured on test-day morning milk samples from 1,940 first-lactation cows

\begin{tabular}{|c|c|c|c|c|c|c|c|c|}
\hline Trait & $\sigma_{p}^{2}$ & $\mathrm{~h}^{2}$ & $\mathrm{~h}_{\text {herd }}$ & $\sigma_{a}^{2} / \sigma_{\text {herd }}^{2}$ & $\sigma_{a}^{2}$ & $\sigma_{a B C N}^{2}$ & $\sigma_{a K C N}^{2}$ & $\sigma_{a B L G}^{2}$ \\
\hline \multicolumn{9}{|c|}{ Milk protein composition ${ }^{3}$} \\
\hline$\alpha_{\mathrm{S} 1}-\mathrm{CN}$ & 2.58 & 0.47 & 0.12 & 3.5 & 1.20 & 1.20 & 1.06 & 1.17 \\
\hline$\alpha_{\mathrm{S} 2}-\mathrm{CN}$ & 1.81 & 0.73 & 0.13 & 4.7 & 1.32 & 1.19 & 1.33 & 1.23 \\
\hline$\beta-\mathrm{CN}$ & 2.14 & 0.25 & 0.16 & 1.4 & 0.54 & 0.47 & 0.49 & 0.54 \\
\hline$\kappa-\mathrm{CN}^{4}$ & 0.30 & 0.64 & 0.12 & 4.9 & 0.19 & 0.20 & 0.12 & 0.19 \\
\hline$\alpha-\mathrm{LA}$ & 0.09 & 0.55 & 0.16 & 2.8 & $4.80 \mathrm{E}-02$ & $4.84 \mathrm{E}-02$ & $4.07 \mathrm{E}-02$ & $4.65 \mathrm{E}-02$ \\
\hline$\beta-\mathrm{LG}$ & 1.42 & 0.80 & 0.05 & 13.9 & 1.14 & 1.15 & 1.21 & 0.11 \\
\hline$\Sigma$ casein $^{5}$ & 2.68 & 0.41 & 0.11 & 3.4 & 1.10 & 1.07 & 1.11 & 0.62 \\
\hline Ewhey ${ }^{6}$ & 1.45 & 0.71 & 0.07 & 9.0 & 1.03 & 1.06 & 1.10 & 0.10 \\
\hline Casein index ${ }^{7}$ & 1.88 & 0.70 & 0.07 & 9.0 & 1.31 & 1.36 & 1.40 & 0.14 \\
\hline Casein yield $^{8}(\mathrm{~kg})$ & $3.01 \mathrm{E}-03$ & 0.26 & 0.35 & 0.5 & $7.71 \mathrm{E}-04$ & $7.05 \mathrm{E}-04$ & $7.75 \mathrm{E}-04$ & 7.65E-04 \\
\hline \multicolumn{9}{|c|}{ Milk production traits } \\
\hline Milk yield (kg) & 5.01 & 0.41 & 0.28 & 1.1 & 2.05 & 1.94 & 2.00 & 2.06 \\
\hline Protein $(\%)$ & 7.17E-02 & 0.66 & 0.19 & 2.8 & $4.72 \mathrm{E}-02$ & $4.71 \mathrm{E}-02$ & $3.97 \mathrm{E}-02$ & $4.71 \mathrm{E}-02$ \\
\hline Fat $(\%)$ & 0.47 & 0.50 & 0.08 & 5.8 & 0.24 & 0.23 & 0.24 & 0.24 \\
\hline Lactose (\%) & $1.95 \mathrm{E}-02$ & 0.62 & 0.06 & 9.6 & $1.21 \mathrm{E}-02$ & $1.20 \mathrm{E}-02$ & $1.19 \mathrm{E}-02$ & $1.21 \mathrm{E}-02$ \\
\hline Protein yield (kg) & $5.07 \mathrm{E}-03$ & 0.24 & 0.36 & 0.4 & $1.19 \mathrm{E}-03$ & $1.08 \mathrm{E}-03$ & $1.19 \mathrm{E}-03$ & $1.21 \mathrm{E}-03$ \\
\hline Fat yield (kg) & $9.15 \mathrm{E}-03$ & 0.39 & 0.24 & 1.2 & $3.60 \mathrm{E}-03$ & 3.61E-03 & $3.53 \mathrm{E}-03$ & 3.61E-03 \\
\hline Lactose yield (kg) & $1.11 \mathrm{E}-02$ & 0.43 & 0.28 & 1.1 & $4.74 \mathrm{E}-03$ & $4.55 \mathrm{E}-03$ & $4.58 \mathrm{E}-03$ & $4.76 \mathrm{E}-03$ \\
\hline
\end{tabular}

${ }^{1} \mathrm{SE}$ between 0.08 and 0.12 .

${ }^{2} \mathrm{SE}$ between 0.02 and 0.03 .

${ }^{3}$ Expressed as percentage of the total protein fraction (wt/wt), except for casein yield.

${ }^{4}$ Only $\kappa-\mathrm{CN}$ in the nonglycosylated mono-phosphorylated form.

${ }^{5} \Sigma$ casein $=\alpha_{\mathrm{S}_{1}-\mathrm{CN}}+\alpha_{\mathrm{S} 2}-\mathrm{CN}+\beta-\mathrm{CN}+\kappa-\mathrm{CN}$.

${ }^{6} \Sigma$ whey $=\alpha-\mathrm{LA}+\beta-\mathrm{LG}$.

${ }^{7}$ Casein index $=\Sigma$ casein $/($ Ecasein $+\Sigma$ whey $) \times 100$.

${ }^{8}$ Casein yield $=\Sigma$ casein $\times$ protein yield.

CN $(-0.61)$ and $\alpha$-LA $(-0.55)$, but positively correlated with $\kappa-\mathrm{CN}(0.55)$. For fat percentage, the genetic correlations with the major milk proteins were similar to protein percentage. Protein yield was positively correlated with $\alpha_{\mathrm{S} 1}-\mathrm{CN}(0.29)$ and negatively correlated with $\kappa-\mathrm{CN}(-0.31)$. Milk yield was positively correlated with $\alpha_{\mathrm{S} 1}-\mathrm{CN}$ (0.52) and negatively correlated with $\kappa-\mathrm{CN}(-0.52)$. Casein yield was positively correlated with $\alpha_{S_{1}-} \mathrm{CN}(0.32)$ and $\Sigma$ casein $(0.35)$, but negatively correlated with $\kappa$-CN $(-0.29)$.

The genetic correlations for protein percentage or fat percentage with the major milk proteins were different from the genetic correlations of lactose percentage with the major milk proteins. The genetic correlations for lactose yield or milk yield with the major milk proteins were similar.

Except for a few correlations, adjusting the data for $\beta$-LG genotypes gave similar correlations to those reported in Table 4. The most important changes in genetic correlations were observed between protein percentage and $\beta-\mathrm{LG}$, which increased from 0.07 to 0.27 . Further, the genetic correlation between protein yield and $\beta-\mathrm{LG}$ decreased from -0.04 to -0.31 , and that between protein yield and casein index increased from 0.09 to 0.49 .

\section{DISCUSSION}

This study reports the heritability and the genetic and phenotypic correlations for the protein composition of milk. Until now, limited information on these parameters was available in the literature. In this study, we determined milk protein composition for a large number of cows using CZE.

\section{Milk Samples}

In this study, only the morning milk sample for cows was analyzed to decrease the transport time from the farm to the laboratory. However, milk production data are usually analyzed by mixing the morning and evening milk sample. Using only the morning sample could have affected our results. McLaren et al. (1998) showed that the concentrations of $\beta-\mathrm{CN}, \alpha-\mathrm{LA}$, and $\beta-\mathrm{LG}$ of cows kept on unrestricted pasture did not significantly differ between morning and evening samples. However, 
McLaren et al. (1998) found a significant difference in $\beta-\mathrm{CN}$ and $\beta-\mathrm{LG}$ concentration between morning and evening samples when the cows had restricted pasture intake.

\section{CZE}

Capillary zone electrophoresis has the capacity to simultaneously quantify the caseins and whey proteins. The reproducibility for CZE was reported by Heck et al. (2008) and varied between $1.5 \%$ for $\alpha_{\mathrm{S} 1}-\mathrm{CN}$ and $5.7 \%$ for $\alpha_{S_{2}}$ CN. These reproducibility values for the relative protein fractions were better than the repeatability values obtained in previous studies (Bobe et al., 1998; Ortega et al., 2003). Moreover, Bobe et al. (1998) could not separate $\alpha-\mathrm{LA}$ and BSA.

\section{Major Milk Proteins}

In our study, $\alpha_{\mathrm{S1}^{-}} \mathrm{CN}$ and $\beta$-CN were the major caseins and $\alpha_{\mathrm{S}_{2}} \mathrm{CN}$ and $\kappa-\mathrm{CN}$ were less abundant, which is the pattern seen in most ruminant species (Bevilacqua et al., 2006). The average relative protein concentration of the major milk proteins was in the range of those previously reported for cattle (Walstra and Jenness, 1984; Bobe et al., 1998), with the exception of $\kappa-\mathrm{CN}$. The mean for $\kappa$-CN (4.03) was lower than previously reported (10.7 and 16.9; Walstra and Jenness, 1984; Bobe et al., 1998). Only about $50 \%$ of the $\kappa-\mathrm{CN}$ was measured in this study; we measured $\kappa-\mathrm{CN}$ in the mono-phosphorylated form, which constitutes a major fraction of $\kappa-\mathrm{CN}$, without the minor $\kappa-\mathrm{CN}$ fractions that occur because of different glycosylation or phosphorylation (Heck et al., 2008). We assumed that the relative concentration of $\kappa$-CN in the mono-phosphorylated form was a good indicator of the relative concentration of $\kappa-\mathrm{CN}$ as a whole. We ignored the effect of variation in $\kappa$-CN phosphorylation and glycosylation between cows when estimating the intraherd heritability and the genetic and phenotypic correlations.

\section{Intraherd Heritability}

In the present study, we modeled herd as a random effect. Including herd as a fixed effect in the model did not influence the heritability estimates for milk protein composition. The intraherd heritability for the protein composition of milk ranged from 0.25 to 0.80 in this study and indicated that it is feasible to alter the milk protein composition using selective breeding. The heritability estimates in this study were similar to or higher than those previously reported for the protein composition of milk from dairy cattle. In particular, 0.25 for $\beta$-CN in our study compared with 0.03 (Kroeker et al.,

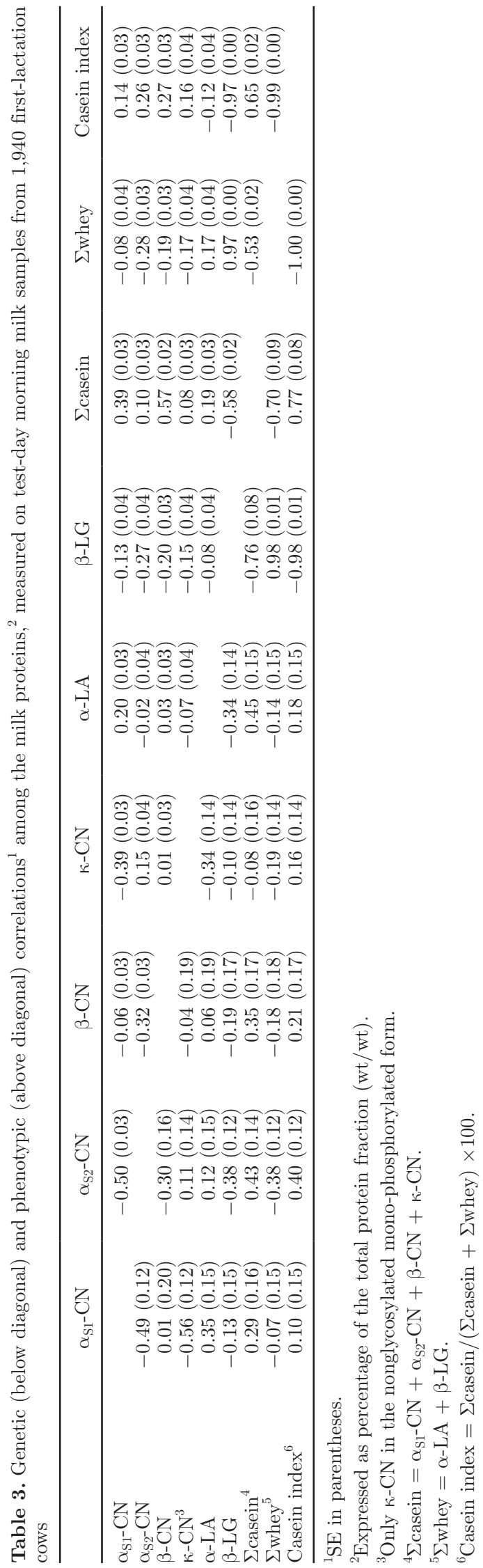

Journal of Dairy Science Vol. 92 No. 3, 2009 
Table 4. Genetic correlations ${ }^{1}$ of milk protein composition traits ${ }^{2}$ with milk production traits, measured on test-day morning milk samples from 1,940 first-lactation cows

\begin{tabular}{|c|c|c|c|c|c|c|c|c|}
\hline Trait & \multicolumn{3}{|c|}{ Percentage (\%) } & \multicolumn{5}{|c|}{ Yield $^{3}$ (kg) } \\
\hline$\alpha_{\mathrm{S} 2}-\mathrm{CN}$ & $0.20(0.14)$ & $0.17(0.15)$ & $-0.05(0.14)$ & $0.15(0.19)$ & $0.21(0.16)$ & $0.00(0.16)$ & $-0.00(0.16)$ & $0.21(0.18)$ \\
\hline$\beta-\mathrm{CN}$ & $-0.03(0.19)$ & $0.11(0.20)$ & $0.10(0.18)$ & $-0.18(0.24$ & $-0.02(0.21)$ & $-0.12(0.21)$ & $-0.13(0.21)$ & $-0.11(0.24)$ \\
\hline$\kappa-\mathrm{CN}^{5}$ & $0.55(0.11)$ & $0.45(0.14)$ & $-0.21(0.14)$ & $-0.31(0.20)$ & $-0.09(0.17)$ & $-0.57(0.14)$ & $-0.52(0.15)$ & $-0.29(0.19)$ \\
\hline$\alpha-\mathrm{LA}$ & $-0.55(0.12)$ & $-0.36(0.14)$ & $0.40(0.13)$ & $-0.07(0.21)$ & $-0.08(0.18)$ & $0.29(0.16)$ & $0.22(0.17)$ & $0.02(0.20)$ \\
\hline$\sum$ whey $^{7}$ & $-0.05(0.15)$ & $0.19(0.15)$ & $0.05(0.14)$ & $-0.07(0.20)$ & $0.11(0.17)$ & $-0.02(0.17)$ & $-0.03(0.17)$ & $-0.20(0.19)$ \\
\hline Casein index $^{8}$ & $0.04(0.15)$ & $-0.19(0.15)$ & $-0.02(0.14)$ & $0.09(0.20)$ & $-0.08(0.17)$ & $0.04(0.17)$ & $0.06(0.17)$ & $0.23(0.19)$ \\
\hline
\end{tabular}

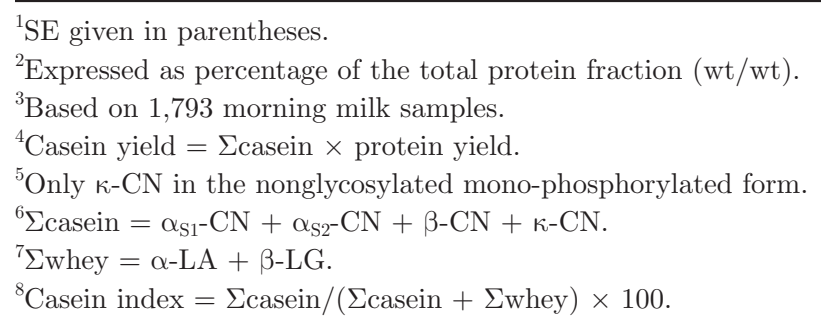

1985 ) or 0.33 to 0.40 (Ikonen et al., 1997), 0.55 for $\alpha$-LA in our study compared with 0.27 (Renner and Kosmack, 1975) or 0.00 to 0.27 (Ikonen et al., 1997) or 0.00 (Bobe et al., 1999), and 0.73 for $\alpha_{S_{2}}-\mathrm{CN}$ in our study compared with 0.00 to 0.31 (Ikonen et al., 1997) or 0.17 (Graml and Pirchner, 2003).

The discrepancy between our results and those reported by Kroeker et al. (1985) is especially remarkable. Kroeker et al. (1985) concluded, based on their estimates, that alteration of the detailed composition of the casein fraction would not be feasible using conventional selection methods. Their study included a data set of over 11,000 test-day records, which suggests that their heritability estimates are accurate. Heritability estimates might differ between studies for several reasons, one of them being the analytical methods used to quantify milk protein composition. We used CZE and Kroeker et al. (1985) used PAGE combined with densitometry. Our CZE method had superior reproducibility, which will decrease the random error variance, and subsequently increase the heritability estimates in our study. Heritability estimates reported by Renner and Kosmack (1975), Ikonen et al. (1997), Bobe et al. (1999), and Graml and Pirchner (2003) were also based on analytical methods different from those used in the present study. The difference in heritability estimates among these studies could be from differences in breeds, in populations, or in allele frequencies. In addition, Ikonen et al. (1997) estimated heritabilities for only 174 samples from 59 Finnish Ayrshire and 155 samples from 55 Finnish Friesian. Bobe et al. (1999) reported heritability estimates based on 592 milk samples from
233 cows on a single farm, and therefore, the standard errors of the estimates were relatively large. Graml and Pirchner (2003) reported heritability estimates that are closer to our heritability estimates, although estimated in Fleckvieh and Braunvieh cattle for roughly 2,000 cows per breed. Graml and Pirchner (2003) combined heritability estimates derived from a sire model and a daughter to dam regression for both breeds, whereas our heritabilities were derived from an animal model in which we accounted for all family relationships among animals.

The polygenic additive genetic variance of the milk protein fractions decreased after adjusting for differences in known $\beta-\mathrm{CN}, \kappa-\mathrm{CN}$, or $\beta$-LG polymorphisms. For $\alpha_{\mathrm{S}^{-}} \mathrm{CN}, \alpha_{\mathrm{S} 2}-\mathrm{CN}$, and $\beta$ - $\mathrm{CN}$, standard errors of estimates were high $(0.29,0.26$, and 0.17 respectively). The $\kappa-\mathrm{CN}$ and $\beta$-LG genotypes had no effect on the polygenic additive genetic variance for $\alpha_{S_{1}}-\mathrm{CN}$ (Table 2), whereas Bobe et al. (1999) found that $\kappa-\mathrm{CN}$ and $\beta-\mathrm{LG}$ genotypes explained a significant part of the genetic control of $\alpha_{S_{1}}$ CN. The decrease in polygenic additive genetic variance for $\beta$-LG fraction from 1.14 to 0.11 is in agreement with Bobe et al. (1999), who concluded that the genetic control of $\beta$-LG fraction is nearly complete by $\beta$-LG genotypes. For some milk protein fractions in particular ( $\kappa-\mathrm{CN}, \beta-\mathrm{LG}, \Sigma$ casein, and casein index), the milk protein polymorphisms explained a considerable part of the genetic variance. However, there is still genetic variation in the rest of the genome to change the relative proportions of milk proteins by selective breeding. Bobe et al. (1999) indicated that there is no genetic variation in the rest of the genome to change 
the relative proportions of milk proteins. Moreover, Bobe et al. (1999) used 592 milk samples from only 233 cows on a single farm.

For both protein percentage (0.66) and protein yield (0.24), the intraherd heritability was in the range previously reported for Holstein cattle: 0.53 (Hayes et al., 1984), 0.61 (Chauhan and Hayes, 1991), and 0.48 (Ikonen et al., 1999) for protein percentage and 0.12 (Hayes et al., 1984) and 0.25 (Chauhan and Hayes, 1991) for protein yield. The intraherd heritability for lactose yield was similar to the intraherd heritability for milk yield, which is in agreement with a previous study by Miglior et al. (2007).

\section{Proportion of Phenotypic Variation Explained by Herd}

The proportion of phenotypic variation of the major milk proteins explained by herd was relatively small and much lower than that of the individual milk fatty acids, which was estimated for the same population of cows and ranged between 0.16 and 0.64 (Stoop et al., 2008). This suggests that herd has a smaller influence on the milk protein composition than it has on milk fat composition. A herd effect may arise from differences in housing, management, and feeding between herds, although we expect that a herd effect mainly reflects differences in feeding. Similarly, Sutton (1989) reported that the scope of changing the milk protein concentration by dietary effects is much smaller than changing the milk fat concentration. Our results support the conclusion that feeding will not have an important effect on the protein composition of milk and confirms results from Coulon et al. (1998), who concluded that the proportion of caseins in cow's milk depends mostly on genetic factors. In addition, Walker et al. (2004) reported that nutrition appears to have little effect on the major milk proteins.

\section{Genetic Correlations Among the Major Milk Proteins}

The 4 casein genes are clustered within a $250-\mathrm{kb}$ region of chromosome 6 in the following order: $\alpha_{S_{1}} \mathrm{CN}$, $\beta-\mathrm{CN}, \alpha_{\mathrm{S}^{-}} \mathrm{CN}$, and $\kappa-\mathrm{CN}$ (Threadgill and Womack, 1990; Bevilacqua et al., 2006). There is homology between the promoter region of all the $\mathrm{Ca}^{2+}$-sensitive casein $\left(\alpha_{\mathrm{S}_{1}}-\mathrm{CN}, \alpha_{\mathrm{S} 2}-\mathrm{CN}\right.$, and $\left.\beta-\mathrm{CN}\right)$ genes (Groenen et al., 1993). Based on these findings, one might expect strong genetic correlations among caseins. Surprisingly, we found the correlations among the caseins to be relatively low, except between $\alpha_{\mathrm{S}^{-}} \mathrm{CN}$ and $\alpha_{\mathrm{S}^{-}} \mathrm{CN}(-0.49)$, and between $\alpha_{\mathrm{S}_{1}}-\mathrm{CN}$ and $\kappa-\mathrm{CN}(-0.56)$. Bevilacqua et al. (2006) showed that the transcription of the casein genes occurs at the same level, but the translation ef- ficiency of the casein messengers is different for the each of the 4 genes. This suggests that there is a general regulation of casein gene expression, but there is a differential posttranscriptional regulation, which might lead to low genetic correlations.

Genetic correlations of casein proteins with whey proteins were relatively low. The strongest genetic correlations were found between $\alpha_{\mathrm{S}_{2}} \mathrm{CN}$ and $\beta$-LG $(-0.38)$, and between $\alpha_{S_{1}}-\mathrm{CN}$ and $\alpha-\mathrm{LA}(0.35)$. These 2 correlations support the suggestion that the regulation of casein and whey genes will, to some extent, involve the same co-factors, hormones, and transcription factors that are involved in the synthesis of milk proteins (Groenen and van der Poel, 1994). The genetic correlations between $\Sigma$ casein and individual whey proteins were stronger than the genetic correlations between $\Sigma$ casein and individual caseins. This confirms results obtained in previous studies that reported a negative relationship between $\beta-\mathrm{LG}$ and casein concentration (van den Berg et al., 1992; Wedholm et al., 2006).

Large amounts of casein increase cheese yield and are, therefore, profitable for the dairy industry. The strong negative genetic correlation between the relative $\beta$-LG concentration and the relative proportion of casein in milk is, therefore, of importance for the cheese production. Ng-Kwai-Hang et al. (1987) and Bobe et al. (1999) showed that genetic variants of $\beta-\mathrm{LG}$ and $\kappa-\mathrm{CN}$ affect the protein composition of milk, which may explain part of the genetic relation that is found. The B-variant of $\beta$-LG is associated with a lower $\beta$-LG concentration (Ng-Kwai-Hang et al., 1987; Bobe et al., 1999), with a higher casein content (van den Berg et al., 1992), and with a somewhat longer renneting time and less heat stability (van den Berg et al., 1992). Boland and Hill (2001) showed in a feasibility study that the selection for the B-variant of $\beta$-LG increased the milk casein and cheese yield per kilogram of milk protein. Thus, selection for the B-variant of $\beta$-LG will result in more casein in milk, which leads to more cheese production, without large influences on cheese properties.

\section{Genetic Correlations of Major Milk Proteins with Milk Production Traits}

For the last few decades, breeding and payment schemes for the dairy industry have been focused on increasing protein yield (Boland et al., 2001). The average milk protein yield in the Netherlands has more than doubled from $148 \mathrm{~kg}$ in 1960 to $325 \mathrm{~kg}$ in 2007 per lactation per cow (CRV, 2008). Selection for protein yield will have a negligible effect on the relative protein concentration of the major milk proteins because the genetic correlations are low to very low (Table 4). This result confirms results reported by Bobe et al. (2007), 
who concluded that selection for milk yield has little effect on the milk protein composition. Selection for protein percentage, however, can be expected to have a small effect on the milk protein composition by increasing the relative protein concentration of $\kappa-\mathrm{CN}$ and decreasing the relative protein concentrations of $\alpha_{\mathrm{S1}^{-}}$ $\mathrm{CN}$ and $\alpha$-LA. Selection for milk yield is expected to have a small effect on the relative protein concentration of the major milk proteins, which is the opposite of protein percentage, by decreasing the relative protein concentration of $\kappa-\mathrm{CN}$ and increasing the relative protein concentrations of $\alpha_{\mathrm{S}_{1}} \mathrm{CN}$ and $\alpha-\mathrm{LA}$. The protein $\alpha-\mathrm{LA}$ is also positively correlated with lactose yield and lactose percentage. This might be a consequence of the fact that the amount of lactose in milk is influenced by the capacity of $\alpha$-LA to maximize its synthesis (Walstra and Jenness, 1984).

\section{CONCLUSIONS}

The heritability for protein composition was moderate to high. Most of the genetic correlations among the major milk proteins were low. The relative $\beta-\mathrm{LG}$ concentration was strongly negatively correlated with the relative proportion of casein in milk, which is of importance for cheese production. Our results suggest interesting possibilities to change the cow's milk protein composition using selective breeding.

\section{ACKNOWLEDGMENTS}

This study is part of the Milk Genomics Initiative, funded by Wageningen University, NZO (Dutch Dairy Organization), breeding company HG, and technology foundation STW. The authors thank the owners of the herds for their help in collecting the data, the Milk Control Station (Zutphen, the Netherlands) for analyzing the milk samples, and CRV (Arnhem, the Netherlands) for supplying pedigrees and milk production data.

\section{REFERENCES}

Bevilacqua, C., J. C. Helbling, G. Miranda, and P. Martin. 2006 Translational efficiency of casein transcripts in the mammary tissue of lactating ruminants. Reprod. Nutr. Dev. 42:567-578.

Bobe, G., D. C. Beitz, A. E. Freeman, and G. L. Lindberg. 1998. Separation and quantification of bovine milk proteins by reversedphase high-performance liquid chromatography. J. Agric. Food Chem. 46:458-463.

Bobe, G., D. C. Beitz, A. E. Freeman, and G. L. Lindberg. 1999. Effect of milk protein genotypes on milk protein composition and its genetic parameter estimates. J. Dairy Sci. 82:2797-2804.

Bobe, G., G. L. Lindberg, A. E. Freeman, and D. C. Beitz. 2007. Short Communication: Composition of milk protein and milk fatty acids is stable for cows differing in genetic merit for milk production. J. Dairy Sci. 90:3955-3960.
Boland, M., and J. Hill. 2001. Genetic selection to increase cheese yield - the Kaikoura experience. Aust. J. Dairy Technol. 56:171176.

Boland, M., A. MacGibbon, and J. Hill. 2001. Designer milks for the new millennium. Livest. Prod. Sci. 72:99-109.

Chauhan, V. P. S., and J. F. Hayes. 1991. Genetic parameters for first lactation milk production and composition traits for Holsteins using multivariate restricted maximum likelihood. J. Dairy Sci. 74:603-610.

Coulon, J.-B., C. Hurtaud, B. Remond, and R. Verite. 1998. Factors contributing to variation in the proportion of casein in cow's milk true protein: A review of recent INRA experiments. J. Dairy Res. 65:375-387.

CRV. 2008. Year Statistics 2007. CRV, Arnhem, the Netherlands.

Feagan, J. T. 1979. Factors affecting protein composition of milk and their significance to dairy processing. Aust. J. Dairy Technol. 34:77-81.

Gilmour, A. R., B. J. Gogel, B. R. Cullis, S. J. Welham, and R. Thompson. 2002. Asreml user guide. Release 1.0. VSN International Ltd., Hemel Hempstead, UK.

Graml, R., and F. Pirchner. 2003. Effects of milk protein loci on content of their proteins. Arch. Tierz. Dummerstorf 46:331-340.

Groenen, M. A. M., R. J. M. Dijkhof, A. J. M. Verstege, and J. J. van der Poel. 1993. The complete sequence of the gene encoding bovine as2-casein. Gene 123:187-193.

Groenen, M. A. M., and J. J. van der Poel. 1994. Regulation of expression of milk protein genes: A review. Livest. Prod. Sci. 38:61-78.

Hayes, J. F., K. F. Ng-Kwai-Hang, and J. E. Moxley. 1984. Heritability of milk casein and genetic and phenotypic correlations with production traits. J. Dairy Sci. 67:841-846.

Heck, J. M. L., C. Olieman, A. Schennink, H. J. F. van Valenberg, M. H. P. W. Visker, R. C. R. Meuldijk, and A. C. M. van Hooijdonk. 2008. Estimation of variation in concentration, phosphorylation and genetic polymorphism of milk proteins using capillary zone electrophoresis. Int. Dairy J. 18:548-555.

Heck, J. M. L., A. Schennink, H. J. F. van Valenberg, H. Bovenhuis, M. H. P. W. Visker, J. A. M. van Arendonk, and A. C. M. van Hooijdonk. 2009. Effects of milk protein variants on the protein composition of bovine milk. J. Dairy Sci. 92:1192-1202.

Ikonen, T., K. Ahlfors, R. Kempe, M. Ojala, and O. Ruottinen. 1999. Genetic parameters for the milk coagulation properties and prevalence of noncoagulating milk in Finnish dairy cows. J. Dairy Sci. 82:205-214.

Ikonen, T., S. Morri, A.-M. Tyrisevä, O. Ruottinen, and M. Ojala. 2004. Genetic and phenotypic correlations between milk coagulation properties, milk production traits, somatic cell count, casein content, and $\mathrm{pH}$ of milk. J. Dairy Sci. 87:458-467.

Ikonen, T., M. Ojala, and E.-L. Syväoja. 1997. Effects of composite casein and $\beta$-lactoglobulin genotypes on renneting properties and composition of bovine milk by assuming an animal model. Agric. Food Sci. Finl. 6:283-294.

Kroeker, E. M., K. F. Ng-Kwai-Hang, J. F. Hayes, and J. E. Moxley. 1985. Heritabilities of relative percentages of major bovine casein and serum proteins in test-day milk samples. J. Dairy Sci. $68: 1346-1348$.

McLaren, R. D., M. J. Auldist, and C. G. Prosser. 1998. Diurnal variation in the protein composition of bovine milk. Proc. N.Z. Soc. Anim. Prod. 58:49-51.

Miglior, F., A. Sewalem, J. Jamrozik, J. Bohmanova, D. M. Lefebvre, and R. K. Moore. 2007. Genetic analyses of milk urea nitrogen and lactose and their relationships with other production traits in Canadian Holstein cattle. J. Dairy Sci. 90:2468-2479.

Ng-Kwai-Hang, K. F., J. F. Hayes, J. E. Moxley, and H. G. Monardes. 1987. Variation in milk protein concentrations associated with genetic polymorphism and environmental factors. J. Dairy Sci. 70:563-570.

Ortega, N., S. M. Albillos, and M. D. Busto. 2003. Application of factorial design and response surface methodology to the analysis of bovine caseins by capillary zone electrophoresis. Food Contr. 14:307-315. 
Renner, E., and U. Kosmack. 1975. Genetische aspekte zum eiweißgehalt und zu den eiweißfraktionen in der Milch. II. Eiweißfraktionen. Züchtungskunde 47:441-457.

Schennink, A., J. M. L. Heck, H. Bovenhuis, M. H. P. W. Visker, H. J. F. van Valenberg, and J. A. M. van Arendonk. 2008. Milk fatty acid unsaturation: Genetic parameters and effects of stearoyl-CoA desaturase (SCD1) and acyl CoA:diacylglycerol acyltransferase 1 (DGAT1). J. Dairy Sci. 91:2135-2143.

Schennink, A., W. M. Stoop, M. H. P. W. Visker, J. M. L. Heck, H. Bovenhuis, J. J. van der Poel, H. J. F. van Valenberg, and J. A. M. van Arendonk. 2007. DGAT1 underlies large genetic variation in milk-fat composition of dairy cows. Anim. Genet. 38:467-473.

Stoop, W. M., H. Bovenhuis, and J. A. M. van Arendonk. 2007. Genetic parameters for milk urea nitrogen in relation to milk production traits. J. Dairy Sci. 90:1981-1986.

Stoop, W. M., J. A. M. van Arendonk, J. M. L. Heck, H. J. F. van Valenberg, and H. Bovenhuis. 2008. Genetic parameters for milk fatty acids and milk production traits of Dutch Holstein-Friesians. J. Dairy Sci. 91:385-394.
Sutton, J. D. 1989. Altering milk composition by feeding. J. Dairy Sci. $72: 2801-2814$.

Threadgill, D. W., and J. E. Womack. 1990. Genomic analysis of the major milk protein genes. Nucleic Acids Res. 18:6935-6942.

van den Berg, G., J. T. M. Escher, P. J. de Koning, and H. Bovenhuis. 1992. Genetic polymorphism of $\kappa$-casein and $\beta$-lactoglobulin in relation to milk composition and processing properties. Neth. Milk Dairy J. 46:145-168.

Walker, G. P., F. R. Dunshea, and P. T. Doyle. 2004. Effects of nutrition and management on the production and composition of milk fat and protein: A review. Aust. J. Agric. Res. 55:1009-1028.

Walstra, P., and R. Jenness, eds. 1984. Protein composition of milk. Dairy Chemistry and Physics. Wiley, New York, NY.

Wedholm, A., L. B. Larsen, H. Lindmark-Månsson, A. H. Karlsson, and A. Andrén. 2006. Effect of protein composition on the cheesemaking properties of milk from individual dairy cows. J. Dairy Sci. 89:3296-3305. 